MAYORS IN THE MIDDLE 



\section{MAYORS IN THE MIDDLE}

P O L I T I C S, R A C E, A N D M A Y O R A L

C O N TR O L O F URBA S CHOOLS

Edited by

Jeffrey R. Henig and Wilbur C. Rich 
Copyright (c) 2004 by Princeton University Press

Published by Princeton University Press, 41 William Street, Princeton, New Jersey 08540

In the United Kingdom: Princeton University Press, 3 Market Place, Woodstock, Oxfordshire OX20 1SY

All Rights Reserved

Library of Congress Cataloging-in-Publication Data

Mayors in the middle : politics, race, and mayoral control of urban schools / edited by Jeffrey R. Henig and Wilbur C. Rich.

p. $\mathrm{cm}$.

Includes bibliographical references and index.

ISBN 0-691-11506-0 (cloth : alk.paper) - ISBN 0-691-11507-9

(pbk. : alk. paper)

1. Education, Urban - Political aspects - United States - Case

studies. 2. Urban policy-United States-Case studies.

3. Mayors-United States-Case studies. 4. Education and

state-United States-Case studies. I. Henig, Jeffrey R., 1951-

II. Rich, Wilbur C.

LC5131.M39 2004

$370^{\prime} .9173^{\prime} 2-\mathrm{dc} 22 \quad 2003054450$

British Library Cataloging-in-Publication Data is available

This book has been composed in Sabon

Printed on acid-free paper. $\infty$

www.pupress.princeton.edu

Printed in the United States of America

$\begin{array}{llllllllll}10 & 9 & 8 & 7 & 6 & 5 & 4 & 3 & 2 & 1\end{array}$ 